\title{
Does Expired-Larvicides Impacted to Plankton Abundance and Diversity?
}

\section{Isni Uswatun Khasanah, Endah Setyaningrum, Tugiyono, Gregorius Nugroho Susanto}

\author{
Jurusan Biologi FMIPA Universitas Lampung, \\ JI. Soemantri Brojonegoro, Gedung Meneng, Bandar Lampung, 35145, Lampung, Indonesia \\ *Email: isniuswatun98@gmail.com
}

\begin{abstract}
The using of chemical insecticides for controlling Aedes aegyptican cause mosquitoes resistant to insecticides. One of the natural insecticides commonly used in controlling Ae. aegypti is Bacillus thuringiensis israelensis (Bti). Bti has been proven effective as larvae of the Ae. aegypti, but its effect on non-target organisms such as plankton is not well known. The purpose of this study was to determine the effect of Bti on plankton abundance and diversity index as a non-target organism. The study was conducted at the Laboratory of Aquatic Molecular Biology, Department of Biology, Faculty of Mathematics and Natural Sciences, the University of Lampung during April 2019 to June 2019, a completely randomized design (CRD) with Bti concentrations of 0 ppm, 20 ppm, 40 ppm, 60 ppm, 80 ppm 100 ppm and Bti expires 20 ppm with 4 replications. Parameters observed were plankton abundance and diversity index and water quality after larvicide treatments on the 5th day. Data was Analysis of Variance (ANOVA) at $\alpha=0.05$. The results showed that Bti treatments did not have a significant effect $(p>0.05)$ on plankton abundance and diversity index at different concentrations, so it's safe to use in the shrimp pond area.
\end{abstract}

Keywords: Aedes aegypti, Bacillus thuringiensis israelensis, plankton

\section{PENDAHULUAN}

Nyamuk Aedes aegypti dikenal sebagai vektor penyakit Demam Berdarah Dengue (DBD). Usaha yang digunakan untuk mengendalikan vektor DBD antara lain yaitu fogging, pemberian abate, kegiatan $3 \mathrm{M}$ plus dan pemeliharaan ikan yang menjadi predator alami larva nyamuk (Perwitasari et al., 2015).

Pengendalian menggunakan insektisida kimia dapat menunjukan hasil yang cepat, tetapi nyamuk dan larva nyamuk menjadi resisten terhadap insektisida tersebut. Oleh karena itu, perlu dilakukan pengendalian populasi nyamuk dengan cara yang lebih aman dan tidak mencemari lingkungan, seperti penggunaan bakteri Bacillus thuringiensis israelensis (Bti) (Komariah dan Malaka, 2011).

Bti digunakan sebagai pengendali biologi dari nyamuk $A e$. aegypti, termasuk dalam kelompok bakteri gram positif dan saat kondisi kurang menguntungkan dapat membentuk spora untuk bertahan hidup. Saat bakteri ini membentuk kapsul, maka terbentuk juga toksin yang akan termakan oleh larva nyamuk. Toksin Bti akan menganggu pencernaan pada larva nyamuk menyebabkan kematian (Poopathi dan Abidha 2011). Konsentrasi Bti yang semakin tinggi pada saat inokulasi menyebabkan peluang kematian nyamuk yang lebih besar. Tempat berkembangbiak nyamuk berpengaruh pada dosis Bti yang diperlukan untuk membunuh larva (Darnely, 2010).

Kegiatan hatchery udang selain menghasilkan keuntungan ekonomi, ternyata menyisakan persoalan jika kegiatan tambak tidak lagi dilanjutkan. Salah satu dampak dari kegiatan tambak yang tidak lagi 
produktif atau terlantar adalah menjadi tempat perindukan nyamuk. Pada hatchery udang terdapat juga beberapa jenis makhluk hidup lainnya, misalnya plankton. Keberadaan plankton dapat dijadikan sebagai bioindikator kondisi perairan karena plankton memiliki batasan toleransi terhadap zat tertentu (Faza, 2012). Perubahan kondisi fisik dan kimia akan mempengaruhi ekosistem perairan dan organisme yang tinggal didalamnya, khususnya keberadaan plankton. Perubahan ekosistem akibat dampak dari pemberian insektisida dan organisme lain yang dapat berperan sebagai agen pengendalian biologi pada larva nyamuk $A e$. aegypti harus dikontrol sekecil mungkin agar tidak mengganggu pertumbuhan dan kelangsungan hidup plankton. Sejauh ini belum banyak dilakukan penelitian tentang pengaruh Bti terhadap organisme non target seperti plankton.

\section{METODE PENELITIAN}

\section{Persiapan alat}

Toples, dan pipet tetes direndam larutan kaporit 100 ppm dalam air tawar selama 4 jam. Selanjutnya peralatan dicuci dengan sabun dan dibilas menggunakan air tawar, kemudian disemprot dengan alkohol $70 \%$, dan dikeringkan. Kemudian aerator, selang dan selang penghubung dipasang pada masing-masing toples kaca yang sudah dicuci bersih.

\section{Persiapan bahan}

Air sampel yang akan digunakan diambil dari tempat perindukan nyamuk yang berada di desa Sukajaya, Lampung Selatan, menggunakan plankton net, dimasukkan dalam toples kaca dengan jumlah 28 dengan masing-masing volume $500 \mathrm{ml}$ dan diletakkan di bawah lampu TL, kemudian diberi pupuk conwy dengan takaran $1 \mathrm{ml} / \mathrm{L}$ untuk pemeliharaan plankton.

\section{Pemberian Bti berbagai konsentrasi}

Air sampel yang sudah dipelihara, diberi larvasida Bti dengan merek dagang yaitu Bactivec yang sudah diencerkan menggunakan air dengan konsentrasi 0 ppm, 20 ppm, 40 ppm, 60 ppm, 80 ppm, 100 ppm, dan kadaluarsa 20 ppm pada hari kedua sesuai konsentrasi yang tertera di label toples yaitu:
$\mathrm{PO}=$ konsentrasi larvasida Bti 0 ppm

P1 = konsentrasi larvasida Bti 20 ppm

$\mathrm{P} 2$ = konsentrasi larvasida Bti 40 ppm

P3 $=$ konsentrasi larvasida Bti 60 ppm

$\mathrm{P} 4=$ konsentrasi larvasida $B t i 80 \mathrm{ppm}$

P5 $=$ konsentrasi larvasida Bti 100 ppm

$\mathrm{K}=$ konsentrasi larvasida $B t i$ kadaluarsa 20 ppm

\section{Pengamatan kualitas air}

Pengamatan kualitas air dilakukan dengan mengukur suhu mengunakan termometer, $\mathrm{pH}$ air dengan menggunakan $\mathrm{pH}$ meter digital, serta salinitas menggunakan refraktometer. Pengamatan dilakukan dengan menghitung kemelimpahan dan indeks keanekaragaman plankton sebagai organisme non target pada pemberian larvasida Bti untuk dilakukan setelah pemberian Bti yang dilakukan pada hari ke2 , kemudian dilakukan pengamatan pada hari ke-7 pemeliharaan plankton (hari ke-5 setelah perlakuan).

\section{Pengamatan plankton}

Pengamatan sampel plankton menggunakan mikroskop binokuler dengan perbesaran 10x40. Perhitungan plankton menggunakan Haemocytometer dengan cara menyisir 5 kotak sedang dalam satu kotak besar di tengah, yaitu pojok kanan dan kiri atas, pojok kanan dan kiri bawah dan tengah Haemocytometer, kemudian menghitung plankton yang tercacah di Haemocytometer. Plankton yang ditemukan dalam 5 kotak sedang diidentifikasi dengan buku Easy identification of the most common freshwater algae (Vuuren, 2006), Phytoplankton Identification Catalogue (Botes, 2001),

\section{Perhitungan plankton}

Perhitungan indeks keanekaragaman $\left(\mathrm{H}^{\prime}\right)$ menggunakan rumus Shannon-Wiener [6]:

$$
H^{\prime}=-\underset{i=1}{S} \text { pi } \ln p i
$$

Keterangan:

$$
\begin{aligned}
& \mathrm{H}^{\prime}=\text { Indeks keanekaragaman jenis } \\
& \mathrm{Pi}=\text { Shannon-Wiener } \\
& \mathrm{ni}=\text { jumlah individu suatu jenis } \\
& \mathrm{N}=\text { jumlah total individu } \\
& \mathrm{S}=\text { jumlah jenis plankton dalam contoh }
\end{aligned}
$$


Perhitungan kemelimpahan plankton dilakukan di bawah mikroskop dengan perbesaran $10 \quad$ x 40 dan dihitung menggunakan haemocytometer. Kemelimpahan plankton per liter dihitung berdasarkan rumus:

$$
\mathrm{Di}=\mathrm{ni}(\mathrm{Vs} / \mathrm{Vc})(1 / \mathrm{A})
$$

Keterangan:

$$
\begin{aligned}
\mathrm{Di}= & \text { Kemelimpahan jenis } \mathrm{i}(\mathrm{ind} / \mathrm{L}) . \\
\mathrm{ni}= & \text { Jumlah individu jenis } \mathrm{i} . \\
\mathrm{V} \mathrm{s}= & \text { Total volume seluruh sampel }(\mathrm{ml}) . \\
\mathrm{VC}= & \text { Volume sampel yang dihitung } \\
& {[(\text { jumlah kotak) }(\mathrm{Vf})](\mathrm{ml}) .} \\
\mathrm{Vf}= & \text { Volume sampel }(\mathrm{ml}) \\
\mathrm{A}= & \text { Volume sampel air yang disaring } \\
& (\mathrm{L})
\end{aligned}
$$

\section{Analisis data}

Data kemelimpahan plankton disajikan dalam bentuk grafik, kemudian dilakukan analisis dengan Analisis of Variance (ANOVA) taraf $a=0,05$. Data indeks keanekaragaman plankton disajikan dalam bentuk grafik, dan data kualitas lingkungan disajikan dalam bentuk tabel, kemudian dianalisis secara deskriptif.

\section{HASIL DAN PEMBAHASAN}

\section{Pengaruh Bti Terhadap Kemelimpahan Plankton}

Hasil penelitian pengaruh Bti terhadap kemelimpahan plankton pada hari ke5(setelah perlakuan) tidak menunjukan pengaruh yang nyata $(p>0,05)$. Rata-rata kemelimpahan plankton pada hari ke-5 setelah diberi perlakuan Bti memiliki nilai terendah berada pada perlakuan Bti 60 ppm dan tertinggi pada Bti 20 ppm (Gambar 1).

Berdasarkan Gambar 1, penelitian pengaruh Bacillus thuringiensis-israelensis (Bti) sebagai larvasida nyamuk Aedes aegypti menunjukan bahwa pemberian Bti dengan konsentrasi yang berbeda tidak berpengaruh nyata pada kemelimpahan plankton. Tidak ditemukan efek negatif perlakuan Btiselama periode 3 tahun pada

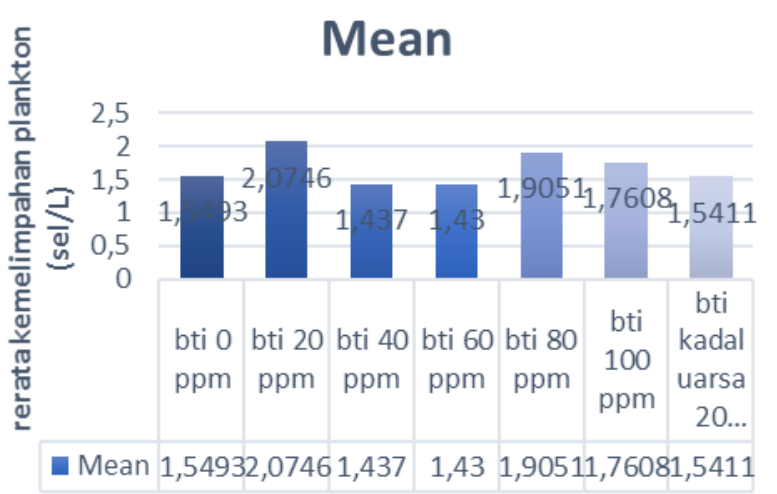

Gambar 1. Rata-rata kemelimpahan plankton hari ke-5 setelah pemberian perlakuan Bti

zooplankton atau burung. Komunitas fauna yang diamati lebih terpengaruh pada faktorfaktor lainnya seperti predasi, dan pengambilan sampel [8]. Tetapi ditemukan efek yang relatif besar pada serangga bentik, paparan larvasida jangka panjang dapat mempengaruhi kemelimpahan serangga. Toksin pada Bti tidak menyerang plankton (tidak termasuk organisme yang memiliki usus atau sistem pencernaan yang bersifat alkali), tetapi hanya menyerang pencernaan beberapa jenis dalam ordo serangga yang spesifik.

Analisis ANOVA pada pengaruh Bti

\begin{tabular}{|c|c|c|c|c|c|c|}
\hline & \multicolumn{6}{|c|}{ ANOVA } \\
\hline & & $\begin{array}{l}\text { Sum of } \\
\text { Squares }\end{array}$ & df & $\begin{array}{l}\text { Mean } \\
\text { Square }\end{array}$ & $\mathrm{F}$ & Sig. \\
\hline & $\begin{array}{l}\text { Between } \\
\text { Groups }\end{array}$ & 1,120 & 6 & 187, & ,366 & 891 \\
\hline & $\begin{array}{l}\text { Within } \\
\text { Groups } \\
\text { Total }\end{array}$ & $\begin{array}{c}9,186 \\
10,307\end{array}$ & $\begin{array}{l}18 \\
24\end{array}$ &, 510 & & \\
\hline
\end{tabular}
terhadap kemelimpahan plankton menunjukan bahwa Bti dengan berbagai konsentrasi tidak berpengaruh nyata terhadap kemelimpahan plankton $(p>0,05)$ disajikan dalam Tabel 1.

Tabel 1. Analisis ANOVA pada kemelimpahan plankton setelah pemberian Bti konsentrasi berbeda 
Dari analisis ANOVA di atas menunjukan bahwa pengaruh Bti terhadap kemelimpahan plankton tidak berbeda nyata secara statistik.

\section{Pengaruh Bti Terhadap Indeks Keanekaragaman Plankton \\ Hasil penelitian pengaruh $B t i$ terhadap indeks keanekaragaman plankton, didapatkan data yang menunjukan bahwa Bti dengan berbagai konsentrasi tidak berpengaruh nyata pada indeks keanekaragaman plankton seperti yang terdapat pada Gambar 2.}

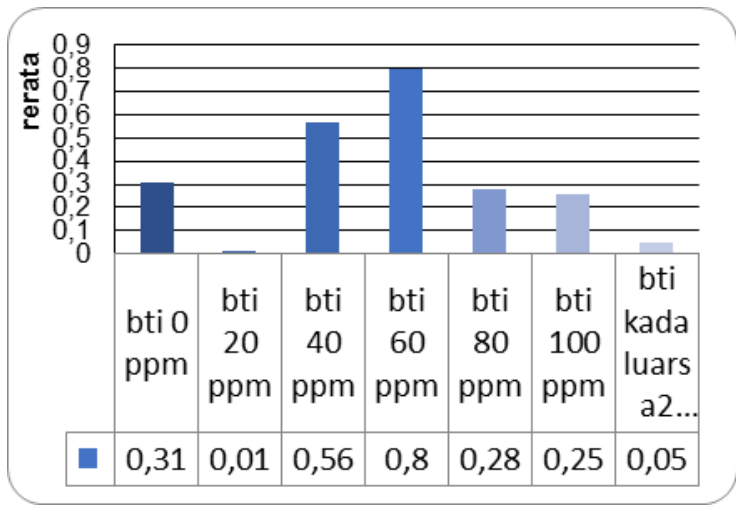

Gambar

2. Rata-rata indeks keanekaragaman plankton hari ke- 5 setelah perlakuan Bti dengan berbagai konsentrasi

Berdasarkan gamabar di atas, indeks keanekaragaman plankton setelah pemberian Bti menunjukan nilai kurang dari 2,306 pada hari ke-5 penelitian dan hasil tersebut dikategorikan sebagai keanekaragaman rendah. Keanekaragaman plankton yang rendah pada penelitian ini kemungkinan karena terjadi dominansi suatu jenis plankton tertentu serta rendahnya variasi plankton yang ditemukan dalam suatu perairan. Jenis plankton yang ditemukan dalam perlakuan dan ulangan tertentu hanya ditemukan dalam jumlah sedikit, dan terkadang hanya dijumpai 1 spesies sehingga nilai keragamannya 0 . Kenaikan atau penurunan indeks keanekaragaman plankton tidak disebabkan oleh adanya toksik dari Bti, kemungkinan terjadi karena teknik pengambilan sampel saat di laboratorium dan di perairan bekas tambak. Kelangkaan suatu kelompok organisme plankton dalam penelitian lebih dimungkinkan karena teknik pengambilan sampel dibandingkan dengan efek perlakuan larvasida pada saat memberantas nyamuk.

\section{Parameter Kualitas Air}

Kualitas air sangat mempengaruhi kehidupan plankton, sehingga perlu dilakukan pengambilan data dengan untuk mengetahui perubahan kualitas air selama pemeliharaan plankton. Kualitas air yang diukur dalam penelitian pengaruh Bti pada plankton yaitu suhu, salinitas dan $\mathrm{pH}$. Terdapat perubahan salinitas pada hari ke-5 setelah perlakuan, salinitas yang diukur berkisar 0-4 ppt. Suhu ruangan yang digunakan adalah $25^{\circ} \mathrm{C}$, dan suhu dalam air kultur plankton adalah $24^{\circ} \mathrm{C}$. Pengukuran $\mathrm{pH}$ pada air selama pemeliharaan plankton menunjukan $\mathrm{pH}$ basa $(>7)$. Data tersebut dapat dilihat pada Tabel 2 :

Tabel 2. Rerata parameter kualitas air

\begin{tabular}{llccc}
\hline No. & Perlakuan & $\begin{array}{c}\text { Suhu } \\
\text { air }\left({ }^{\circ} \mathrm{C}\right)\end{array}$ & $\mathrm{pH}$ & $\begin{array}{c}\text { Salinitas } \\
\text { (ppt) }\end{array}$ \\
\hline 1 & P0 (Bti 0 ppm) & 24 & 8,8 & 0 \\
2 & $\begin{array}{l}\text { P1 (Bti } 20 \\
\text { ppm) }\end{array}$ & 24 & 8,8 & 0 \\
3 & $\begin{array}{l}\text { P2 (Bti } 40 \\
\text { ppm) }\end{array}$ & 24 & 8,8 & 0 \\
4 & $\begin{array}{l}\text { P3 (Bti } 60 \\
\text { ppm) }\end{array}$ & 24 & 8,8 & 0 \\
5 & $\begin{array}{l}\text { P4 (Bti } 80 \\
\text { ppm) }\end{array}$ & 24 & 8,8 & 0 \\
6 & $\begin{array}{l}\text { P5 (Bti } 100 \\
\text { ppm) }\end{array}$ & 24 & 8,8 & 0 \\
7 & $\begin{array}{l}\text { K (Bti } \\
\text { kadaluarsa } 20 \\
\text { ppm) }\end{array}$ & 24 & 8,9 & 2 \\
\hline
\end{tabular}

Suhu air di pada saat pengambilan sampel yaitu $30^{\circ} \mathrm{C}$, sedangkan suhu ruangan saat pemeliharaan plankton berkisar antara 23$25^{\circ} \mathrm{C}$. Suhu ruangan maupun suhu lingkungan tersebut masih dalam batas normal, karena suhu ideal untuk pertumbuhan plankton di perairan tropis adalah $21-35^{\circ} \mathrm{C}$ (Wardoyo, 1983).

Kebanyakan biota aquatik memiliki sensitifitas pada perubahan $\mathrm{pH}$ dan umumnya $\mathrm{pH}$ 6,6-8,5 adalah kisaran $\mathrm{pH}$ yang layak untuk kehidupan organisme perairan (Welch, 1952). Perairan produktif adalah perairan dengan $\mathrm{pH}$ 6,7-7,5 dan perairan yang tidak poduktif memiliki $\mathrm{pH} 5,5$ 6,5 dan 7,5-8,5 (Banerjea, 1967). Pada saat 
pengambilan sampel air, $\mathrm{pH}$ yang terukur menggunakan $\mathrm{pH}$ meter sebesar 7,4 yang berarti mendekati $\mathrm{pH}$ air netral dan masih termasuk $\mathrm{pH}$ yang layak untuk kehidupan plankton. Sedangkan $\mathrm{pH}$ saat kultur di laboratorium berkisar antara 8,7-8,9 yang menunjukan $\mathrm{pH}$ tersebut termasuk basa dan saat $\mathrm{pH}$ melewati 8,5 berarti air tersebut sudah berkurang kelayakannya untuk mendukung kehidupan serta produktifitas plankton.

Pengambilan sampel air di wilayah perairan bekas tambak menunjukan salintas 2-3 ppt. Pada hari ke-5 memiliki salinitas 0-4 ppt. Hari ke-5 memiliki salinitas air yang cenderung seperti air tawar dan menjadi payau. Penyebaran salinitas di suatu perairan dipengaruhi oleh faktor tertentu, seperti penguapan, aliran permukaan, jumlah air tawar yang masuk ke perairan, kedalaman laut, pasang surut, musim dan curah hujan (Nurhayati, 2010).

\section{KESIMPULAN}

Kesimpulan penelitian ini adalah pemberian Bacillus thuringiensis-israelensis (Bti) sebagai larvasida nyamuk Aedes aegypti dengan beberapa konsentrasi tidak berpengaruh secara nyata terhadap kemelimpahan dan indeks keanekaragaman plankton, sehingga aman digunakan untuk mengendalikan nyamuk vektor DBD pada wilayah tambak udang.

\section{DAFTAR PUSTAKA}

Perwitasari, D., D.A. Musadad, H.S.P. Manalu, A. Munif. (2015). Effect of Several Dosages of Bacillus thuringiensis var Israelensis Serotype $\mathrm{H}-14$ Against Aedes aegypti Larvae in West Kalimantan. Jurnal Ekologi Kesehatan, 14 (3), 229-237.

Komariah, Pratita S., dan Malaka T. (2011). Pengendalian Vektor. Jurnal Kesehatan Bina Husada, 6(1).
Poopathi, S. and Abidha, S. (2011). Mosquitocidal bacterial toxins (Bacillus sphaericus and Bacillus thuringiensis serovar israelensis): Mode ofaction, cytopathological effects and mechanism of resistance. Journal of Physiology and Pathophysiology, 1(3), 22-38.

Darnely. (2010). Penggunaan Bacillus thuringiensis israelensis untuk Memberantas Aedes aegypti. Majalah Kedokteran FK UKI 2010 XXVII No.4.

Faza, F. (2012). Struktur Komunitas Plankton di Sungai Prasanggrahan dari Bagian Hulu (Bogor, Jawa Barat) hingga Bagian Hilir (Kembangan DKI Jakarta). Jakarta: Laporan Penelitian Universitas Indonesia.

Wardoyo, S.T.H. (1983). Metode Pengukuran Kualitas Air, Training: Penyusunan Analisis Mengenai Dampak Lingkungan. Bogor: Institut Pertanian Bogor.

Welch, P.S. (1952). Limnological Methods. USA: Mc Grow-hill Book Company Inc.

Banerjea, S.M. (1967). Water Quality and Soil Condition of Fish Pond in Some Stages of India in Relation to Fish Production. Indian J. Fish, 14(1-2), 115-114.

Nurhayati. (2010). Fluktuasi suhu dan salinitas di perairan pantai Teluk Jakarta pada bulan Februari dan Juni 2009. Dinamika Ekosistem Perairan Kepulauan Seribu, Teluk Jakarta. Jakarta: Pusat Penelitian Oseanografi. Lembaga Ilmu Pengetahuan Indonesia. 